\title{
St. Augustinegrass Rooting following Preemergence Herbicide Application
}

\author{
Lambert B. McCarty and D. Wayne Porter \\ Department of Environmental Horticulture, P.O. Box 110670, University of Florida, Gainesville, \\ FL 32611-0670 \\ Daniel L. Colvin and Donn G. Shilling \\ Department of Agronomy, University of Florida, Gainesville, FL 32611-0500 \\ David W. Hall \\ KBN Engineering and Applied Sciences, Gainesville, FL 32605
}

Additional index words. atrazine, dithiopyr, isoxaben, metolachlor, oxadiazon, pendimethalin, sod, turfgrass

\begin{abstract}
Greenhouse studies were conducted at the Univ. of Florida to evaluate the effects of preemergence herbicides on St. Augustinegrass [Stenotaphrum secundatum (Walt.) Kuntze] rooting. Metolachlor, atrazine, metolachlor + atrazine, isoxahen, pendimethalin, dithiopyr, and oxadiazon were applied to soil columns followed by placement of St. Augustinegrass sod on the treated soil. Root elongation and biomass were measured following application. Plants treated with dithiopyr and pendimethalin had no measurable root elongation and root biomass was severely $(>70 \%)$ reduced at the study's conclusion (33 days). Root biomass was unaffected following isoxaben and oxadiazon treatments, but oxadiazon applied at $3.4 \mathrm{~kg}^{-h^{-1}}{ }^{-1}$ reduced root length by $50 \%$. Atrazine at $2.2 \mathrm{~kg} \cdot \mathrm{ha}^{-1}$ and metolachlor + atrazine at $2.2+2.2 \mathrm{~kg} \cdot \mathrm{ha}^{-1}$, did not reduce root length in one study, while the remaining atrazine and metolachlor + atrazine treatments reduced cumulative root length and total root biomass $20 \%$

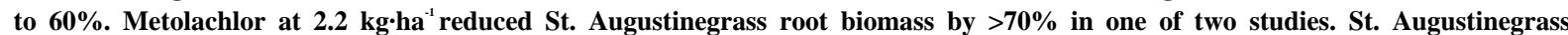
root elongation rate was linear or quadratic in response to all treatments. However, the rate of root elongation was similar to the untreated control for plants treated with isoxaben or oxadiazon. Chemical names used: 6-chloro-N-ethyl-N'-(lmethylethyl)-1,3,5-triazine-2,4-diamine(atrazine);S,S-dimethyl2-(difluoromethyl)-4-(2-methylpropyl)-6-(t $\sim$ fluoromethyl)-

3,5-pyridinecarbothioate (dithiopyr); $\mathrm{N}$-[3-(1-ethyl-1-methylpropyl)-5-isoxazolyl]-2,6-dimethoxybenzamide (isoxaben); 2chloro-N-(2-ethyl- 6-methylphenyl)-N-(2-methoxy-1-methylethyl)acetamide (metolachlor); 3-[2,4-dichloro-5-(1methylethoxy)phenyl]-5-(1,1-dimethylethyl)-1,3,4-oxadiazol-2-(3H)-one $\quad$ (oxadiazon); $\quad \mathrm{N}$-(1-ethylpropyl)-3,4-dimethyl-2,6-
\end{abstract} dinitrobenzenamine (pendimethalin).

St. Augustinegrass sod production involves harvesting turf rolls or pieces while leaving thin grass strips. Stolons from these strips reestablish the field, and 8 to 14 months are generally required before the next crop is mature (McCarty and Cisar, 1989). Herbicide options in immature St. Augustinegrass have been limited due to economics or severe injury to stolons. The dinitroaniline herbicides can be used successfully on mature St. Augustinegrass, but have not been used on immature St. Augustinegrass due to potential inhibition of root growth (Bingham, 1974). In agronomic crops, dinitroaniline herbicides can cause swelling at the root tip and a lack of normal lateral root development following application (Appleby and Valverde, 1989; Bayer et al., 1967; Gentner and Burk, 1968; Hackskaylo and Amato, 1968; Parka and Soper, 1977). Impeded root development could severely reduce St. Augustinegrass nutrient and water uptake and encourage removal of unpegged stolons during mowing, thus resulting in poor lifting at harvest. These factors also may extend the regrowth time following a harvest and potentially increase production costs.

Preemergence herbicide use in St. Augustinegrass sod production has been limited primarily to members of the triazine herbicide family, such as atrazine and simazine [6-chloro-N,N'-diethyl1,3,5-triazine-2,4-diamine] (White and Busey, 1988). These are useful for preemergence and early postemergence control of many

Received for publication 23 May 1994. Accepted for publication 22 Sept. 1994. Contribution from the Florida Agricultural Experiment Station Journal Series No. R-93835. The authors thank David G. Spencer for his assistance with this study. The cost of publishing this paper was defrayed in part by the payment of page charges. Under postal regulations, this paper therefore must be hereby marked advertisment solely to indicate this fact. broadleaf weeds. At 7 and 28 days after application, neither atrazine nor simazine applied at $4.5 \mathrm{~kg} \cdot \mathrm{ha}^{-1}$ resulted in any St. Augustinegrass foliar injury (Burt, 1964a, 1964b). Although atrazine applied to St. Augustinegrass has slowed regrowth initially, effective weed control soon allowed for competitive turf growth (Peacock and Dudeck, 1982).

Metolachlor recently became available for use on St. Augustinegrass, but little research has been conducted to determine its effects on regrowth of sod roots and shoots. Oxadiazon also is available, but is not economically feasible for most sod farming operations. Therefore, greenhouse studies were conducted to characterize the short-term St. Augustinegrass rooting response to these and other preemergence herbicides.

\section{Materials and Methods}

Studies were conducted in the Plant Science Greenhouse Complex, Gainesville, Fla. usingroot observation containers (ROCs) to quantify root growth on a periodic basis following herbicide treatments. The ROCs were made of clear plexiglass $15 \mathrm{~cm}$ in diameter and $\approx 54 \mathrm{~cm}$ in length. To prevent soil loss, filter paper was placed at the bottom of each ROC over drainage holes. Soil used was an Arredondo fine sand (loamy, siliceous, hyperthermic Grossarenic Paleudult) consisting of $2.5 \%$ organic matter, 5\% clay, $4 \%$ silt, and $91 \%$ sand with a $\mathrm{pH}$ of 6.0 . The soil was fumigated with methyl bromide and sieved to remove debris. The ROCs were placed upright on a level, and soil settled to ensure uniform density by repeating a process of saturating with water then draining to field capacity for each $15-\mathrm{cm}$ increment until the soil was $\approx 5 \mathrm{~cm}$ from the container top. The ROCs were placed on 
Table 1. St. Augustinegrass root biomass and root elongation following herbicide applications.

\begin{tabular}{|c|c|c|c|c|c|c|c|c|c|c|c|c|c|}
\hline \multirow[b]{3}{*}{ Treatments } & \multirow[b]{3}{*}{ Rate } & \multicolumn{6}{|c|}{ Expt. 1} & \multicolumn{6}{|c|}{ Expt. 2} \\
\hline & & \multicolumn{4}{|c|}{ Rool biomass (mg) } & \multirow[b]{2}{*}{ Total } & \multirow{2}{*}{$\begin{array}{l}\text { Root } \\
\text { length } \\
(\mathrm{mm})\end{array}$} & \multicolumn{4}{|c|}{ Root biomass (mg) } & \multirow[b]{2}{*}{ Total } & \multirow{2}{*}{$\begin{array}{l}\text { Root } \\
\text { length } \\
(\mathrm{mm})\end{array}$} \\
\hline & & $0-15 \mathrm{~cm}$ & $15-30 \mathrm{~cm}$ & $130-45 \mathrm{~cm}$ & $>45 \mathrm{~cm}$ & & & $0-15 \mathrm{~cm}$ & $15-30 \mathrm{~cm}$ & $30-45 \mathrm{~cm}$ & $>45 \mathrm{~cm}$ & & \\
\hline Untreated & --- & $746 a^{\prime}$ & $202 a b$ & $82 a b$ & $16 a$ & $1047 a$ & $426 a$ & $218 \mathrm{a}$ & $83 a$ & $52 a$ & $9 a$ & $362 \mathrm{a}$ & $275 \mathrm{a}$ \\
\hline Atrazine & 1.1 & $463 c-e$ & $136 \mathrm{c}-\mathrm{e}$ & 44 de & $5 c-e$ & $648 c-e$ & $326 \mathrm{~b}-\mathrm{d}$ & $143 b-e$ & $35 \mathrm{bc}$ & $10 \mathrm{~cd}$ & $2 \mathrm{bc}$ & $191 \mathrm{c}-\mathrm{e}$ & $136 b-d$ \\
\hline Atrazine & 2.2 & $524 \mathrm{a}-\mathrm{d}$ & $136 \mathrm{c}-\mathrm{e}$ & $45 \mathrm{de}$ & $4 \mathrm{de}$ & $710 \mathrm{~b}-\mathrm{e}$ & $313 \mathrm{~cd}$ & $143 b-c$ & $46 \mathrm{~b}$ & $30 \mathrm{bc}$ & $3 \mathrm{bc}$ & $222 \mathrm{~b}-\mathrm{d}$ & $221 \mathrm{ab}$ \\
\hline Isoxaben & 0.6 & $648 a-c$ & $190 a-c$ & $76 \mathrm{bc}$ & $10 b c$ & $924 a-c$ & $364 \mathrm{bc}$ & $222 a$ & $54 \mathrm{ab}$ & $25 \mathrm{bc}$ & $5 a-c$ & $306 a b$ & $261 \mathrm{a}$ \\
\hline Isoxaben & 1.1 & $617 a-c$ & $159 a-d$ & $54 \mathrm{~cd}$ & $6 \mathrm{~cd}$ & $838 \mathrm{a}-\mathrm{d}$ & $337 \mathrm{hc}$ & $207 \mathrm{ah}$ & $42 \mathrm{~h}$ & $29 \mathrm{bc}$ & $3 \mathrm{bc}$ & $282 a-c$ & 223 ah \\
\hline Metolachlor & 1.1 & $372 \mathrm{~d}-\mathrm{f}$ & $141 b-e$ & $41 \mathrm{de}$ & $2 \mathrm{de}$ & $556 \mathrm{~d}-\mathrm{f}$ & $271 \mathrm{de}$ & $134 c-e$ & 29 b-d & $20 b-d$ & $6 a b$ & $189 \mathrm{c}-\mathrm{e}$ & $150 \mathrm{bc}$ \\
\hline Metolachlor & 2.2 & $330 \mathrm{~d}-\mathrm{g}$ & $89 \mathrm{e}$ & 23 ef & $1 \mathrm{e}$ & $443 \mathrm{e}-\mathrm{g}$ & $198 \mathrm{f}$ & $85 \mathrm{ef}$ & $12 \mathrm{~cd}$ & $3 d$ & $0 \mathrm{c}$ & $100 e-f$ & $48 \mathrm{de}$ \\
\hline $\begin{array}{l}\text { Metolachlor } 1 . \\
\text { + Atrazine }\end{array}$ & $.1+1.1$ & $480 \mathrm{~b}-\mathrm{e}$ & $128 \mathrm{c}-\mathrm{e}$ & $31 \mathrm{de}$ & 4 de & $643 \mathrm{c}-\mathrm{e}$ & $215 \mathrm{ef}$ & $106 \mathrm{ef}$ & $29 b-d$ & $13 \mathrm{~cd}$ & $3 \mathrm{bc}$ & $151 \mathrm{~d}-\mathrm{f}$ & $114 \mathrm{~cd}$ \\
\hline $\begin{array}{c}\text { Metolachlor } 2 \\
+ \text { Atrazine }\end{array}$ & $.2+2.2$ & $494 \mathrm{~b}-\mathrm{c}$ & $108 \mathrm{de}$ & $.35 \mathrm{de}$ & $2 \mathrm{de}$ & $639 \mathrm{c}-\mathrm{e}$ & 240 ef & $117 d-f$ & $56 \mathrm{ab}$ & $37 \mathrm{ah}$ & $10 a$ & $220 h-d$ & $197 \mathrm{a}-\mathrm{c}$ \\
\hline Oxadiazon & 1.7 & $703 \mathrm{ab}$ & $202 \mathrm{ab}$ & $105 a$ & $15 a b$ & $1044 a$ & $381 a b$ & $198 a-c$ & $41 \mathrm{~b}$ & $25 \mathrm{bc}$ & $6 a b$ & $270 a-c$ & $247 a$ \\
\hline Oxadiazon & 3.4 & $639 \mathrm{a}-\mathrm{c}$ & $222 \mathbf{a}$ & $78 \mathrm{bc}$ & $14 a b$ & $952 a b$ & $356 b c$ & $180 \mathrm{a}-\mathrm{d}$ & $42 \mathrm{~b}$ & $27 b c$ & $2 b c$ & $251 \mathrm{a}-\mathrm{d}$ & $137 b-c$ \\
\hline Pendimethalin & 1.1 & $213 \mathrm{fg}$ & $0 \mathrm{f}$ & $0 \mathrm{f}$ & $0 \mathrm{e}$ & $213 \mathrm{gh}$ & $0 \mathrm{~g}$ & 94 ef & $0 \mathrm{~d}$ & $0 \mathrm{~d}$ & $0 \mathrm{c}$ & 94 ef & $0 \mathrm{e}$ \\
\hline Pendimethalin & 2.2 & $275 \mathrm{e}-\mathrm{g}$ & $0 \mathrm{f}$ & $0 \mathrm{f}$ & $0 \mathrm{e}$ & $275 \mathrm{f}-\mathrm{h}$ & $0 \mathrm{~g}$ & 84 ef & $0 d$ & $0 d$ & $0 \mathrm{c}$ & 84 ef & $0 \mathrm{e}$ \\
\hline Dithiopyr & 0.4 & $148 \mathrm{~g}$ & $0 \mathrm{f}$ & $0 \mathrm{f}$ & $0 \mathrm{e}$ & $148 \mathrm{~h}$ & () g & $53 \mathrm{f}$ & $0 \mathrm{~d}$ & $0 \mathrm{~d}$ & $0 \mathrm{c}$ & $53 \mathrm{f}$ & $0 \mathrm{e}$ \\
\hline Dithiopyr & 0.8 & $114 \mathrm{~g}$ & $0 \mathrm{f}$ & $0 \mathrm{f}$ & $0 \mathrm{e}$ & $114 \mathrm{~h}$ & $0 \mathrm{~g}$ & $46 \mathrm{f}$ & $0 \mathrm{~d}$ & $0 \mathrm{~d}$ & $0 \mathrm{c}$ & $46 \mathrm{f}$ & $0 \mathrm{e}$ \\
\hline
\end{tabular}

${ }^{7}$ Means with the same letter are not significant different at $P=0.10$.

shelving at a $20^{\circ}$ angle from vertical and saturated with water. The containers drained for $48 \mathrm{~h}$ before herbicide application and sod placement and each container was wrapped with aluminum foil to prevent light penetration.

Herbicide treatments (Table 1) were applied using a pressurized $\mathrm{CO}_{2}$-powered backpack micro applicator. Rates listed are the labeled or expected label rate and one-half rate for these herbicides on warm-season turfgrasses grown on sandy soils (McCarty, 1994). A total volume of $75 \mathrm{ml}$ water was used, while granular herbicides were hand applied. Mature St. Augustinegrass plugs 15 $\mathrm{cm}$ in diameter were removed from field plots and laid on the treated soil surface within the ROCs and placed on a greenhouse bench. Before planting, the St. Augustinegrass plug roots were trimmed below the thatch layer. Natural lighting was used, and day/night temperatures maintained at $\approx 30 / 13 \mathrm{C}$. Plants were watered twice daily with $0.75 \mathrm{~cm}$ water per ROC for a 2 week period following planting and herbicide application. Afterwards, water was applied once daily at $0.75 \mathrm{~cm}$ per ROC. Liquid $20-20-20$ fertilizer with micronutrients was applied at $49 \mathrm{~kg}$ N/ha 14 days after planting. Turf was trimmed to a 7.6-cm height 7 and 14 days after planting then every 4 days after the fertilization for the remainder of the study. Stolons also were trimmed within the perimeter of the ROCs.

Experiments were initiated on 6 June 1991 and 1 Aug. 1991. Root elongation measurements commenced 10 days after planting and continued every 2 days for 30 and 36 days after planting in Expts. 1 and 2, respectively. Root elongation rate was evaluated by marking ROC exteriors to indicate the change in length of the root apex between sampling periods. Five roots per ROC were measured and the mean growth per ROC was used as one replicate.

Final root biomass was determined by dividing harvested roots into $15-\mathrm{cm}$ intervals $(0-15,115-30,30-45$, and $>45 \mathrm{~cm})$ after being washed and sieved. Roots were then placed into a drying oven at $50 \mathrm{C}$ for a minimum of $60 \mathrm{~h}$ (until no weight change occurred) and weighed.

The experimental design was a randomized complete block with four replications. Data were subjected to analysis of variance to test for treatment effects and interactions. Regression analysis was used to establish a dose response based on root elongation rate. The least significant difference (LSD) procedure $(P=0.10)$ was used to compare treatment effects.

\section{Results and Discussion}

Root biomass. Significant experiment $\times$ treatment interaction occurred for root biomass, therefore, experiments are presented separately. In Expt. 1, root biomass was unaffected in the upper 45 $\mathrm{cm}$ with oxadiazon or within the top $30 \mathrm{~cm}$ with isoxaben (Table 1). Isoxaben treatments reduced root biomass $10 \%$ to $40 \%$ compared to the untreated at soil depths $>30 \mathrm{~cm}$. Both rates of atrazine, $1.1 \mathrm{~kg} \cdot \mathrm{ha}^{-1}$ of metolachlor, and metolachlor + atrazine reduced root biomass by $30 \%$ to $60 \%$. Metolachlorat $2.2 \mathrm{~kg} \cdot \mathrm{ha}^{-1}$ reduced root biomass $50 \%$ to $76 \%$ while pendimethalin and dithiopyr reduced root biomass by $>90 \%$.

In Expt. 2, root biomass was unaffected in the upper $15 \mathrm{~cm}$ by isoxaben and oxadiazon treatments but was reduced $40 \%$ to $50 \%$ at deeper soil depths (Table 1). Root growth was reduced $30 \%$ to $65 \%$ following atrazine and metolachlor + atrazine rates. Metolachlor at $2.2 \mathrm{~kg} \cdot \mathrm{ha}^{-1}$ and both rates of pendimethalin reduced root biomass from $60 \%$ to $70 \%$ while dithiopyr-treated plants had root reductions of $\gg 75 \%$ in the upper $1.5 \mathrm{~cm}$. Root biomass at deeper soil depths was reduced $\gg 60 \%$ with $1.1 \mathrm{~kg} \cdot \mathrm{ha}^{-1}$ of metolachlor, while $>85 \%$ reduction followed $2.2 \mathrm{~kg} \cdot \mathrm{ha}^{-1}$ of metolachlor and all pendimethalin and dithiopyr treatments.

Based on both experiments, neither isoxaben nor oxadiazon affected total root biomass (Table 1). Overall, atrazine, metolachlor at $1.1 \mathrm{~kg} \cdot \mathrm{ha}^{-1}$, and metolachlor + atrazine reduced mean root biomass $30 \%$ to $60 \%$. Severe reductions of $70 \%$ to $80 \%$ followed metolachlor at $2.2 \mathrm{~kg} \cdot \mathrm{ha}^{-1}$ and both rates of pendimethalin, while $>90 \%$ reduction followed both rates of dithiopyr.

Root elongation. Quadratic and linear curves indicated that all herbicides differentially influenced root elongation for Expt. 1 (Fig. 1). Root growth responded in aquadratic manner to metolachlor with slow growth initially, increasing $\approx 16$ days after treatment 
(DAT). Final predicted root length 30 DAT was $\approx 200 \mathrm{~mm}$ and 270 $\mathrm{mm}$ for the 1.1 and $2.2 \mathrm{~kg} \cdot \mathrm{ha}^{-1}$ metolachlor rates, respectively, compared to $-440 \mathrm{~mm}$ for the untreated roots. Predicted root growth following atrazine treatments was linear, with a final root length between 310 and $340 \mathrm{~mm}$. Rooting response following metolachlor + atrazine was similar to metolachlor applied alone and was greatest following metolachlor + atrazine at $2.2+2.2$ $\mathrm{kg} \cdot \mathrm{ha}^{-1}(\approx 360 \mathrm{~mm})$. Isoxaben caused a quadratic response with final predicted root length of 300 to $315 \mathrm{~mm}$. Although the higher rate of oxadiazon reduced root growth, the rate of elongation was similar regardless of treatment. Pendimethalin and dithiopyr totally inhibited root elongation.

Predicted root elongation in Expt. 2 was highest for the untreated plants 36 DAT (Fig. 2). Atrazine at $2.2 \mathrm{~kg} \cdot \mathrm{ha}^{-1}$ had initial root length similar to the untreated plants 16 to 20 DAT but eventually reduced predicted root elongation by $23 \%$. St. Augustinegrass root elongation following applications of atrazine at $1.1 \mathrm{~kg} \cdot \mathrm{ha}^{-1}$ responded in a quadratic manner, with slow growth initially through 16 to 18 DAT and a final root length of $135 \mathrm{~mm}$. Predicted root elongation following metolachlor at $2.2 \mathrm{~kg} \cdot \mathrm{ha}^{-1}$ was negligible 20 DAT with root lengths of only $45 \mathrm{~mm}$ at the end of the study. In comparison, metolachlor at $1.1 \mathrm{~kg} \cdot \mathrm{ha}^{-1}$ resulted in predicted root elongation of $145 \mathrm{~mm}$. Metolachlor + atrazine treatment resulted in linear root elongation, with the $1.1+1.1$ $\mathrm{kg} \cdot \mathrm{ha} \mathrm{a}^{-1}$ treatment causing the least amount of predicted root elongation $(100 \mathrm{~mm})$.

Quadratic root growth responses also were produced in Expt. 2 following treatments of isoxaben and oxadiazon (Fig. 2). Root development was similar to untreated plants following isoxaben treatment regardless of rate, but oxadiazon at $1.7 \mathrm{~kg} \cdot \mathrm{ha} \mathrm{H}^{-1}$ reduced root elongation by $11 \%$. St. Augustinegrass treated with oxadiazon at 3.4 $\mathrm{kg} \cdot \mathrm{ha}^{-1}$ had reduced root growth until $\approx 20$ DAT with a sharp increase to $140 \mathrm{~mm}$ thereafter. As was the case in Expt 1, dithiopyr and pendimethalin completely inhibited measurable root elongation.

Cumulative mean St. Augustinegrass root length was similar or slightly ( $15 \%$ to $20 \%$ ) reduced at the conclusion of both experiments for the untreated plants and those treated with isoxaben at $0.6 \mathrm{~kg} \cdot \mathrm{ha}^{-1}$ and oxadiazon at $1.7 \mathrm{~kg} \cdot \mathrm{ha}^{-1}$. Isoxaben at $1.1 \mathrm{~kg} \cdot \mathrm{ha}^{-1}$, both rates of atrazine, metolachlor at $1.1 \mathrm{~kg} \cdot \mathrm{ha}^{-1}$, oxadiazon at 3.4 $\mathrm{kg} \cdot \mathrm{ha}^{-1}$, and metolachlor + atrazine reduced root length $40 \%$ to $50 \%$. A $50 \%$ to $85 \%$ root length reduction followed metolachlor at $2.2 \mathrm{~kg} \cdot \mathrm{ha} \mathrm{a}^{-1}$ while no measurable St. Augustinegrass root growth occurred for pendimethalin and dithiopyr.

Overall, oxadiazon and isoxaben had the least effect on root length, biomass, and growth rate. Previous work with oxadiazon at $4.5 \mathrm{~kg} \cdot \mathrm{ha}^{-1}$ indicated no effect on root biomass of three zoysiagrass
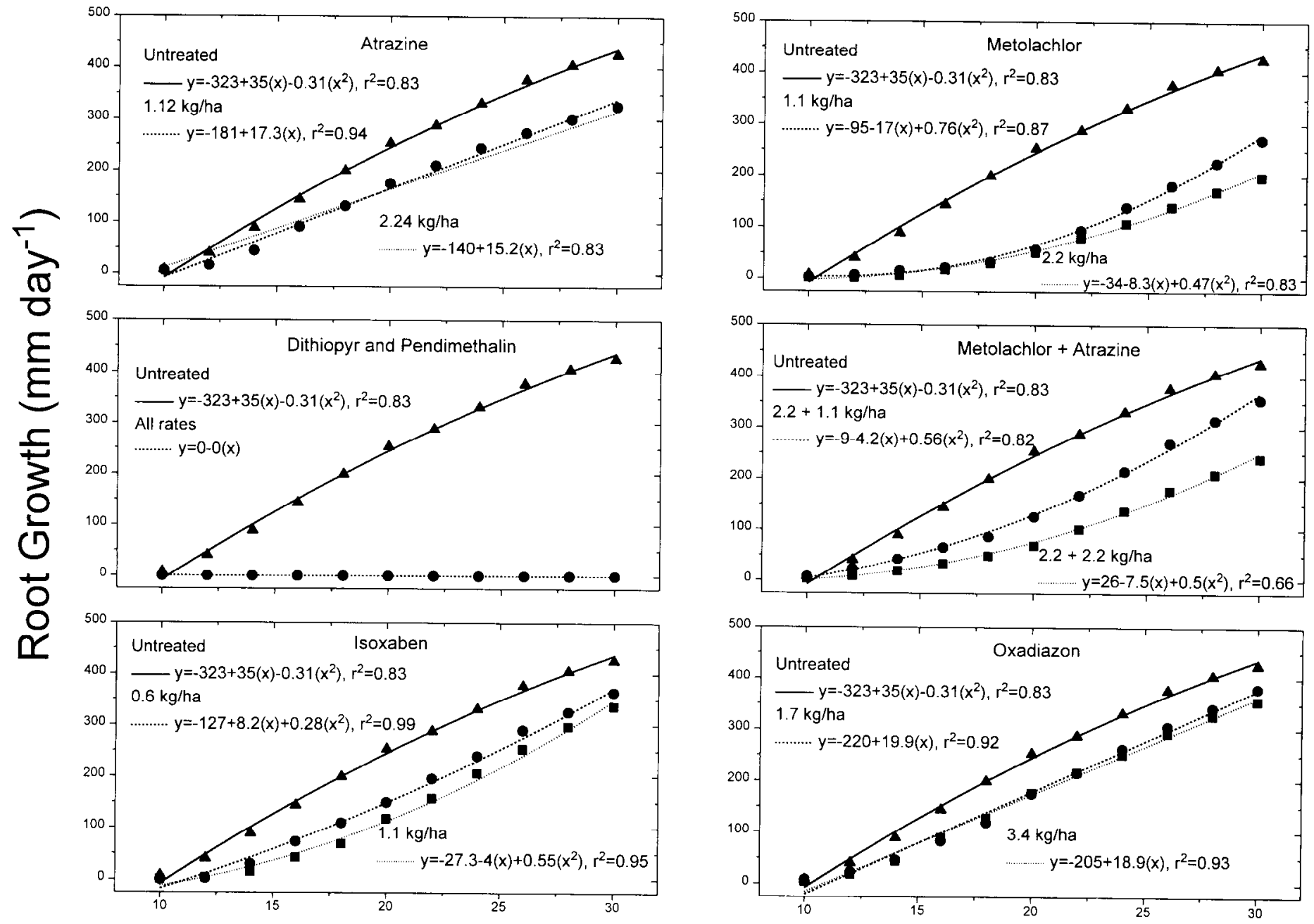

\section{Days After Treatment}

Fig. I. St. Augustinegrass root elongation rate pattern following the indicated herbicide treatments compared to the untreated, Expt. 1. 


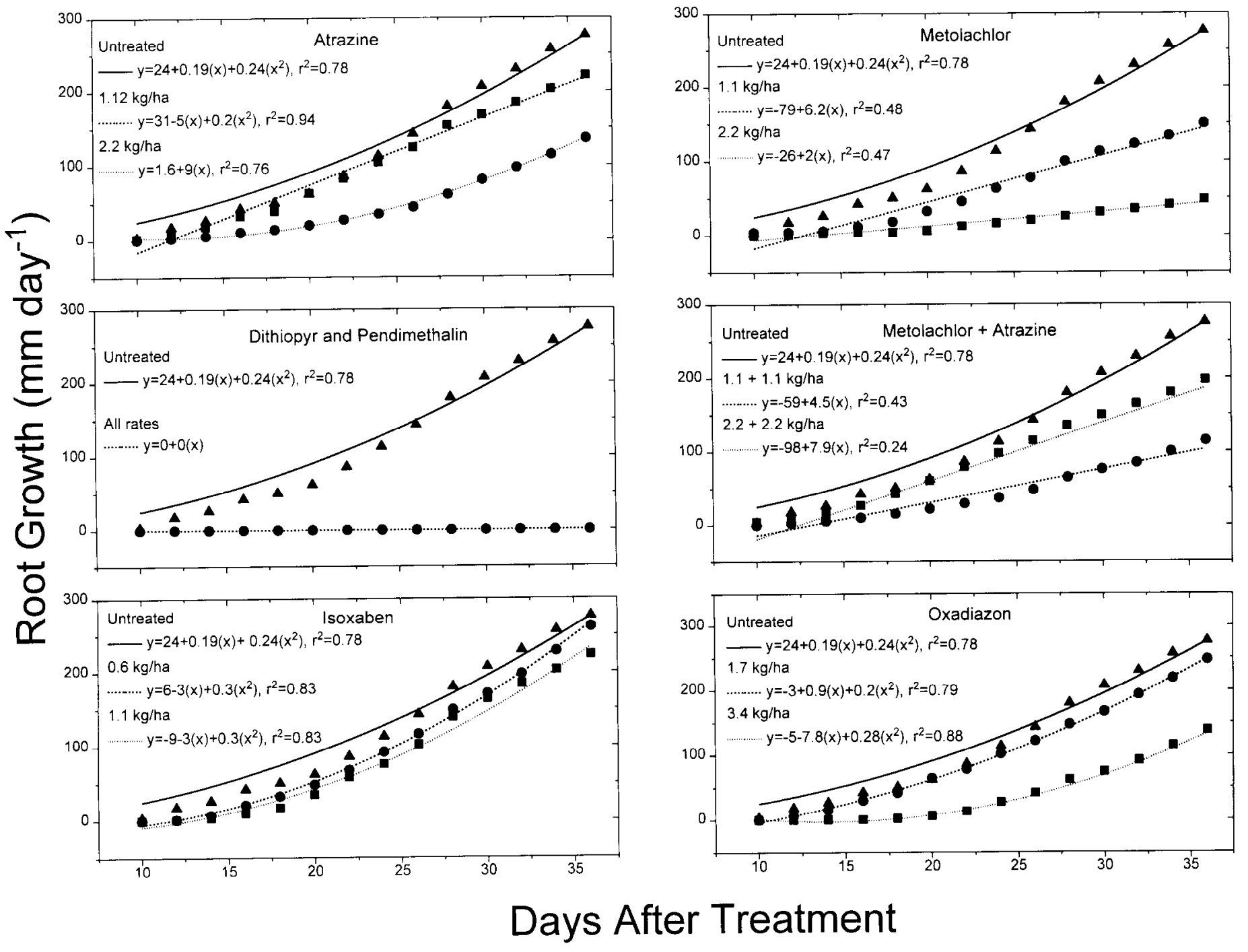

Fig. 1 St. Augustinegrass root elongation rate pattern following the indicated herbicide treatmentl compared to the untreated, Expt. 2

(Zoysia spp.) and four bermudagrass (Cynodon spp.) cultivars (Johnson, 1980). Oxadiazon appears to be safe for use in sod production with minor disruption of St. Augustinegrass rooting.

In our study, intermediate reductions of rooting followed various treatments with metolachlor and atrazine. Previous research has indicated that St. Augustinegrass established from sprigs was not affected by atrazine applied at 1.1 or $2.2 \mathrm{~kg} \cdot \mathrm{ha}^{-1}$, but survival and growth rates were reduced following use of simazine (Johnson, 1973). Centipedegrass (Eremochloa ophiuroides) stolon growth and survival was reduced following atrazine and simazine treatments in several studies (Coats, 197.5; Turner and Dickens, 1987) but were unaffected in another (Turner et al., 1990). Based on research reported herein, the use of metolachlor, atrazine, or combination thereof may cause minor to intermediate St. Augustinegrass rooting delay, but should pose little long-term problem.

Dithiopyr and pendimethalin had the greatest negative effect on root growth in these studies. This is somewhat expected due to the known effects of these compounds on root growth. However, if applied to mature sod, negative effects are greatly diminished (Sharpe et al., 1989; Turner et al., 1990). Due to the potential of becoming root bound, our studies were short-term (-33 days each). Longer evaluation periods could have resulted in less growth inhibition.

\section{Literature Cited}

Appleby A.P. and B.E. Valverde. 1989. Behavior of dinitroaniline herbicides in plants. Weed Technol. 3: 198-206.

Bayer, D.E., C.L. Foy, T.E. Mallory, and E.G. Cutter. 1967. Morphological and histological effects of trifluralin on root development. Amer. J. Bot. 54:945-952.

Bingham, S.W. 1974. Influence of selected herbicides on rooting of turfgrass sod, p. 372-377. In: E.C. Roberts (ed.). Proc. 2nd Intl. Turfgrass Res. Conf., June, 1978. Amer. Soc. Agron., Crop Sci. Soc. Amer.; Madison, Wis.

Burt, E.O. 1964a Tolerance of warm-season turfgrasses to preemergence herbicides: Preliminary report. Proc. Soil and Crop Sci. Soc. Florida 24:137-141.

Burt, E.O. 1964b. Tolerance of warm season turfgrasses to herbicides. Proc. Southern Weed Conf. p. 123-126.

Coats, G.E. 1975. Effect of preemergence herbicides on centipedegrass establishment. Proc. Southern Weed Sci. Sot. 28:81. (Abstr.)

Gentner, W.A. and L.C. Burk. 1968. Gross morphological and cytological effects of nitralin on corn roots. Weed Sci. 16:259-260.

Hackskaylo, J. and V.A. Amato. 1968. Effect of trifluralin on roots of corn and cotton. Weed Sci. 16:513-515.

Johnson, B.J. 1973. Establishment of centipede grass and St.Augustine grass with the aid of chemicals. Agron. J. 65:959-962.

Johnson, B.J. 1980. Root growth of southern turf cultivars as affected by 
herbicides. Weed Sci. 28:526-528.

McCarty, L.B. 1994. University of Florida's pest control recommendations for turfgrass managers. Florida Coop. Ext. Serv. SS-ORH-004.

McCarty, L.B. and J.L. Cisar. 1989. Basic guidelines for sod production in Florida. Florida Coop. Ext. Serv. Bul. 260.

Parka S.J. and O.F. Soper. 1977. The physiology and mode of action of the dinitroaniline herbicides. Weed Sci. 25:79-87.

Peacock, C.H., and A.E. Dudeck. 1982. Effects of atrazine on St. Augustinegrass establishment. Proc. Florida State Hort. Soc. 95:164 165 .
Sharpe, S.S., R. Dickens, and D.L. Turner. 1989. Herbicide effects on tensile strength of bermudagrass (Cynodon dactylon) sod. Weed Technol. 3:353-357.

Turner, D.L. and R. Dickens. 1987. Atrazine effects on tensile strength of centipedegrass sod. Agron. J. 79:39-42.

Turner, D.L., S.S. Sharpe, and R. Dickens. 1990. Herbicide effects on tensile strength and rooting of centipedegrass sod. HortScience 25:541544.

White, R.W. and P. Busey. 1988. History of turfgrass production in Florida. Proc. Florida Turfgrass Conf. 36: 100-113. 